\title{
Six-Twelve Leukemia
}

National Cancer Institute

\section{Source}

National Cancer Institute. Six-Twelve Leukemia. NCI Thesaurus. Code C97905.

Six-twelve leukemia ( $\sim 5 \mathrm{~kb})$ is encoded by the human RNF217-AS1 gene. This non-coding RNA may play a role in B-cell acute lymphoblastic leukemia. 